Василь Каплінський, доктор педагогічних наук, доцент кафедри педагогіки Вінницького державного педагогічного університету імені Михайла Коцюбинського vasuliukaplinskiy@gmail.com

\title{
ПРОФЕСІЙНЕ СТАНОВЛЕННЯ МАЙБУТНЬОГО ВЧИТЕЛЯ В ПРОЦЕСІ ЗАГАЛЬНОПЕДАГОГІЧНОЇ ПІДГОТОВКИ
}

Визначено етапи дослідження проблеми професійного становлення майбутнього вчителя: теоретико-аналітичний, діагностично-пошуковий, експериментальний, підсумково-узагальнювальний. Розкрито практичне значення дослідження зазначеної проблеми. Доведено, щь застосування авторської технології сприяє як професійному, так $i$ особистісному зростанню студентів у проиесі загальнопедагогічної підготовки.

Результати проведеного дослідження свідчать, щяо запропонований системний підхід до організації професійного становлення створює для студентів реальні можливості віднайти свій власний шлях професійного вдосконалення, поступово здійснюючи перехід на більи високий його рівень.

Ключові слова: майбутні вчителі, професійне становлення, система професійного становлення, загальнопедагогічна підготовка, суб'єкт-суб'єктні відносини, загальнопедагогічна компетентність, педагогічні відеофрагменти, проблемні педагогічні ситуаиії, професійне самовиховання.

\section{Kaplinski Wasyl. Ustanawianie zawodowe przysztego nauczyciela w procesie ogólnego przygotowania pedagogicznego.}

Określono etapy badania problemu ustanawiania zawodowego przyszłego nauczyciela: teoretyczno-analityczny, diagnostyczno-poszukiwawczy, eksperymentalny, podsumowujacy. Ujawniono praktyczne znaczenie badania tego problemu. Udowodniono, że zastosowanie technologii autorskiej sprzyja zarówno rozwoju zawodowemu, jak i osobistemu wzrastaniu studentów w procesie ogólnego przygotowania pedagogicznego. Wyniki badania pokazuja, że zaproponowane systematyczne podejście do organizacji rozwoju zawodowego stwarza studentom realne możliwości znalezienia własnego sposobu rozwoju zawodowego, stopniowo przechodzac na wyższy poziom.

Słowa kluczowe: przyszli nauczyciele, ustanawianie zawodowe, system ustanawiania zawodowego, ogólne przygotowanie pedagogiczne, relacje podmiotowo-subiektywne, ogólna kompetencja pedagogiczna, filmowe urywki pedagogiczne, problematyczne sytuacje pedagogiczne, samokształcenie zawodowe.

\section{Kaplinsky Vasyl. Professional formation of the future teacher in the process of general pedagogical preparation.}

The stages of teacher's professional establishment are determined. They are theoretic analysis, diagnostic research, experimental and conclusive stages. The practical evaluation of this research

is shown. It is proved that practical usage of the results of the research contributes to both professional and personal development of students in the process of pedagogic training. The results of the research claim that this particular approach to the organization of students' professional forming create for them real opportunities to find their own way of professional self-improvement, transferring gradually to its higher level: from low to basic, from changing the reproductive activity to the reconstructive, growing constantly to the highest creative level. 
In the context of reforming and updating education in Ukraine, the orientation of the educational process to the professional formation of the future teacher is of particular importance, as professionalism ensures the success not only of the educational sector, but of society as a whole, the readiness for dynamic civilizational changes and creative self-realization in the XXI society. The modern school will be able to respond to the challenges of society qualitatively only when competent, socially active, creative and creative alumni of the new generation of higher education institution will professionally grow. And the personalty will be capable to be ready with changes, could take independent decision in difficult and professional situations in life.

Key words: future teachers, professional development, general pedagogical training, the system of professional development, general pedagogical competence, subject-subject relations, pedagogical video fragments, problem pedagogical situations, professional self-education.

Постановка проблеми в загальному вигляді та її зв'язок із важливими науковими і практичними завданнями. Проблема професійного становлення вчителя належить до найбільш актуальних проблем у сучасному освітньому просторі. Вона відображає дисбаланс між запитами українського суспільства на висококваліфікованих педагогічних працівників та реальним станом педагогічної освіти. «Сьогодення вимагає запровадження в освітню теорію й практику сучасних підходів, тобто модернізації практики реалізації вищої освіти» [4, с. 4], пошуку нових ресурсів і нового її технологічного забезпечення.

В умовах реформування та оновлення освіти в Україні як «джерела динамічного розвитку особистості впродовж життя» $[13$, с. 8], соціального замовлення на педагога нової генерації особливого значення набуває орієнтація освітнього процесу на професійне становлення майбутнього вчителя, оскільки саме професіоналізм забезпечує успіхи не тільки освітньої галузі, а й суспільства загалом, готовність до динамічних цивілізаційних змін та творчої самореалізації в суспільстві XXI століття.

Сучасна школа зможе якісно реагувати на виклики суспільства лише тоді, коли в іiї стіни прийдуть компетентні, соціально активні, креативні й творчі випускники ВЗО нової генерації, здатні до самозмін, до самостійного прийняття виважених рішень у складних, суперечливих, постійно мінливих ситуаціях професійно-педагогічної діяльності та життя загалом. «Здійснення масштабних освітніх реформ, - наголошується в «Концепції розвитку педагогічної освіти», - неможливе без докорінної модернізації всієї системи підготовки педагогічних працівників. Орієнтація суспільства на європейські стандарти й цінності, кращі світові традиції вимагають відповідних системних змін і в сфері освіти. Наріжним каменем таких змін є покращення якості освітнього процесу, а відтак - якості підготовки вчителя.

Значна частина здобувачів педагогічної освіти апріорі не орієнтована на подальшу діяльність у галузі освіти і не зацікавлена в здобутті професійних компетентностей» [9, с. 4].

I дійсно, часто випускник педагогічного університету може продемонструвати високий рівень академічних досягнень під час навчання та під час державної атестації, але це не $\epsilon$ гарантом його успішності в професійній діяльності, якщо майбутній учитель не був зорієнтованим на формування високого рівня, поряд 3 фаховою, загальнопедагогічної компетентності. Випускника, який оволодів фаховими знаннями, не досягнувши належного рівня загальнопедагогічної компетентності, ще не можна назвати повноцінним педагогом, готовим до успішної й продуктивної професійної діяльності, оскільки якість учителяпрофесіонала значною мірою визначається його професійно-педагогічним ресурсом, здобутим під час навчання у ВЗО.

Аналіз основних досліджень і публікацій із зазначеної проблеми. Базовими для обгрунтування проблеми професійно-особистісного становлення майбутнього вчителя $є$ педагогічні дослідження В. Андрущенка, І. Беха, Г. Васяновича, С. Гончаренка, Р. Гуревича, Е. Зеєра, І. Зязюна, О. Кокуна, Л. Мітіної, В. Кременя, Н. Ничкало, Л. Пуховської, В. Радула та ін. Професійне становлення та розвиток особистості майбутнього вчителя в умовах професійної підготовки в закладах вищої педагогічної освіти досліджували О. Акімова, 
О. Антонова, Н. Бідюк, М. Гриньова, О. Дубасенюк, М. Кадемія, А. Коломієць, М. Лещенко, О. Савченко, В. Шахов та ін.

Аналіз досліджень і публікацій, у яких започатковано вирішення зазначеної проблеми, свідчить про багатовекторний пошук науковців у цьому напрямі: вивчення філософських засад (О. Базалук); психологічних умов професійного становлення студентів 3ВО (І. Лотова, А. Маркова); шляхів оптимізації професійного становлення вчителя (В. Орлов); чинників, що сприяють професійному зростанню особистості (В. Андронов, О. Вознюк, А. Деркач, В. Петрук, О. Коберник, О. Огієнко); особливостей педагогічної підтримки розвитку особистості (О. Газман) тощо.

У контексті дослідження особливої теоретико-методологічної ваги набувають наукові розробки проблеми професійної підготовки вчителів, які висвітлено в працях А. Алексюка, Є. Барбіної, В. Галузяка, Н. Кузьміної, Н. Лазаренко, В. Лугового, С. Сисоєвої, Л.Шевченко та ін.

Суттєвий інтерес для нашого дослідження становлять праці, де розглядаються виховні аспекти професійної підготовки майбутніх педагогів різних напрямів: технологій (В. Бойчук), музики (Б. Брилін), фізичного виховання (І. Асаулюк, Н. Степанченко), початкової школи (О. Голюк, О. Демченко, М. Чепіль) тощо.

Проблемам професійного становлення вчителів різних напрямів підготовки присвячено чимало дисертаційних робіт, зокрема досліджувалися теоретичні та методичні засади підготовки майбутніх педагогів до безперервного професійного саморозвитку (В. Фрицюк), професійне становлення майбутніх учителів мистецьких дисциплін (В. Орлов), майбутніх тренерів-викладачів (С. Павлюк); професійне становлення педагога в інформаційному середовищі (Г. Абрамян), у процесі гуманітарної підготовки (О. Булгакова), у процесі вивчення курсу «Основи педагогічної майстерності» (Л. Малаканова), в освітньому процесі педагогічного коледжу (С. Абрамович, А. Билков); педагогічні умови становлення професійної діяльності майбутнього вчителя (Н. Святкіна), професійного становлення молодих учителів (Л. Литвин, С. Петрусенко, Т. Чувакова), майбутніх учителів музики (Ю. Локарєва, А. Пєтєлін, Я. Сверлюк), математики (О. Ковальчук); педагогічна діагностика професійного становлення майбутнього вчителя у ЗВО (Г. Микитюк, О. Фадєєва) та ін.

Окреслення невирішених питань, порушених у статті. Аналіз наукової літератури 3 проблеми професійного становлення майбутнього вчителя свідчить про різнобічне розроблення певних аспектів визначеної проблеми, але недостатньо дослідженою залишається система професійного становлення майбутнього вчителя в процесі загальнопедагогічної підготовки в умовах педагогічного університету, iї методологічне та теоретичне обгрунтування. Більшість наукових праць присвячено становленню учителяпрофесіонала певного напряму підготовки. Актуальність означеної проблеми, необхідність розв'язання окреслених суперечностей, відсутність фундаментальних системних досліджень проблеми професійного становлення майбутнього вчителя, зокрема в процесі загальнопедагогічної підготовки, зумовили вибір означеної проблеми дослідження.

Мета статті полягає у визначенні теоретичних позицій розв'язання проблеми професійного становлення майбутнього вчителя в процесі загальнопедагогічної підготовки.

Виклад основного матеріалу 3 обгрунтуванням отриманих наукових результатів. Освітня кваліфікація педагога є одночасно й професійною лише тоді, коли супроводжується комплексом спеціальних заходів сприяння входженню в професію, які спонукають студента спеціально цілеспрямовувати на це свої зусилля під час навчання. Ототожнення освітньої діяльності 3 професійною може залишити поза увагою реалізацію специфічних функцій останньої і стати гальмівним чинником професійного становлення. 3 іншого боку, у процесі студіювання вищої педагогічної освіти має зростати не лише освітній і професіональний рівень, а й сама людина як особистість, яка в сучасних умовах передусім має бути особистістю інноваційного типу, здатною до опанування та практичного використання новітніх технологій і методик навчання та виховання. 
Саме тому доволі складний та багатогранний процес професійного становлення майбутніх педагогів потребує врахування специфіки студентського віку, а його методологічним орієнтиром має бути особистісний, з позицій якого студент як особистість потребує не меншої уваги, ніж студент як майбутній професіонал. «Поряд 3 когнітивним розвитком учителя, - зазначає англійський психолог Р. Бернс, - важливою вимогою, яку необхідно враховувати в процесі професійної підготовки, $\epsilon$ його загальний психологічний тонус $\mathrm{i}$ адекватність особистісної регуляції» [2, с. 314].

Професійне становлення не буде повноцінним процесом, якщо професійний прогрес не супроводжуватиметься особистісним, спрямованим на якісне перетворення самого себе. Саме тому нами в подальшому буде вживатись, окрім «особистісне становлення», термін «професійно-особистісне становлення».

Початок успішної педагогічної діяльності - проектування й реалізація власного індивідуального маршруту професійного становлення, починаючи з першого року навчання, 3 обов'язковою орієнтацією на його ефективний результат через надбання професійно важливих якостей і наближення до якісного професійного стану.

Передбачаємо, що в результаті професійного становлення під впливом зовнішніх (соціально-педагогічних) i внутрішніх (власної активності, спрямованої на самовдосконалення) чинників мають відбуватися прогресивні зміни в професійному й особистісному планах: формування загальнопедагогічної та фахової компетентності, педагогічної спрямованості, готовності до постійного професійного зростання, нарощування інтелектуального та духовного потенціалу, а відтак, присвоєння цінностей майбутньої професії, які виступають основою формування ціннісно - професійної позиції, що регулює процес вирішення професійних проблем.

Професійне становлення характеризується тим, відзначає Е. Зеер, узагальнюючи власні дослідження в цій галузі, що в навчально-професійній діяльності, крім знань, умінь i навичок, формуються «професійно важливі особистісні якості», такі, як ерудиція, практичне й діагностичне мислення, інтуїція, спостережливість, передбачення та рефлексія. Тому навчання, що супроводжує професійне становлення, на думку автора, має будуватися на діяльнісній основі [5, с. 198].

Прогнозуємо, що якісний результат професійного становлення залежитиме від якісного процесу його організації: якості вимог (чітке визначення цілей, стандартів, норм), якості ресурсів (навчально-методичне забезпечення, кадровий потенціал), якості технологій. Організовуючи процес професійного становлення в контексті очікувань суспільства, його обов'язково потрібно спрямовувати на успіх, що виступає важливим мотиваційним чинником на кожному його етапі. Тут велике значення має прагнення студента та його власні зусилля щодо постійного особистісно-професійного самовдосконалення, мотиваційними чинниками якого є бачення перспектив педагогічної професії, привабливість професійної кар'єри педагога та престижність її здобуття.

Сформованість внутрішніх мотивів і орієнтація на професійне становлення набувають важливого значення ще тому, що цей процес не завершується в момент одержання диплома про освіту та певного рівня кваліфікації випускника, а продовжується шляхом набуття досвіду безпосередньої педагогічної діяльності, оскільки професійне становлення $\epsilon$ тривалим, практично нескінченним, процесом професійного розвитку людини.

Одна 3 найважливіших теоретичних позицій, на якій ми базувались, організовуючи процес професійного становлення, - науковий висновок Л. Мітіної, яка, здійснюючи аналіз професійного розвитку й професійного становлення у взаємозалежності, розрізняє їх за наступним критерієм: домінуючими в професійному розвитку $є$ внутрішні чинники, у професійному становленні - зовнішні [10, с. 152-178]. За нашим переконанням, зовнішні чинники лише тоді будуть мати позитивне значення в професійному становленні майбутнього вчителя, коли він відчуватиме кваліфіковані педагогічну підтримку й педагогічний супровід з боку викладача як головного орієнтира професійного становлення й 
провідника позитивних змін, здатного обирати та якісно застосовувати відповідні педагогічні технології. Майбутній педагог, який досягнув високого рівня професійного становлення, має бути мотивованим, знати, уміти спілкуватись, організувати педагогічну діяльність, активно включатися в неї, забезпечувати ії успішність і самовдосконалюватись.

Провідна ідея дослідження грунтується на положенні про те, що професійне становлення майбутніх учителів в умовах педагогічного університету - це динамічний процес, спрямований на формування готовності до педагогічної діяльності, результатом якого $\epsilon$ досягнення інтегрованої цілісності сформованих особистісних і професійних якостей, що проявляються як оптимальні рівні загальнопедагогічної компетентності.

Методологічними позиціями дослідження проблеми професійного становлення майбутнього вчителя в процесі загальнопедагогічної підготовки є концептуальні положення філософії, психології, педагогіки; культурно-освітні, історичні закономірності розвитку суспільства; фундаментальні наукові підходи: системний, діяльнісний, особистісно орієнтований, компетентнісний, культурологічний, аксіологічний, акмеологічний, полісуб'єктний, синергетичний, інтегративний, структурно-функціональний тощо; психологічні підходи, що відображають особливості становлення особистості: психодинамічний (3. Фрейд), аналітичний (К. Юнг), соціокультурний (К. Хорні), диспозиційний (Г. Олпорт), біхевіористичний (Б. Скіннер), когнітивний (Дж. Келлі), феноменологічний (К. Роджерс), соціально-психологічний (А. Петровський).

Теоретичними позиціями, окрім зазначених вище, $\epsilon$ система вихідних параметрів, що забезпечують розуміння сутності особистісно-професійного становлення майбутнього вчителя як процесу розвитку інтегративної характеристики особистості загальнопедагогічної компетентності, котра поєднує в собі знання, уміння, навички, педагогічні здібності, духовну, соціальну, психологічну, мотиваційну зрілість та сформованість самості особистості. Результатом професійного становлення педагога визначено його загальнопедагогічну компетентність, що трактується як інтегративна якість, яка визначає його професійну готовність, професійну спрямованість і особливості вияву на оптимальному рівні компонентів сфери професійної діяльності та потребує тривалого періоду професійно зорієнтованого розвитку.

Дослідження здійснювалось у чотири етапи. На теоретико-аналітичному відбувалось вивчення теорії та практики загальнопедагогічної підготовки майбутніх учителів у 3ВО; системний аналіз наукової літератури з проблеми дослідження; визначення методологічних засад професійного становлення; накопичення емпіричного матеріалу; конкретизація мети й завдань дослідження; розроблення методики теоретичного й експериментального дослідження, критеріїв і показників загальнопедагогічної компетентності як результату професійного становлення майбутніх педагогів. Діагностично-пошуковий передбачав дослідно-експериментальну перевірку стану професійного становлення майбутніх учителів у процесі загальнопедагогічної підготовки; теоретичне обгрунтування й розроблення системи професійного становлення майбутніх учителів у процесі загальнопедагогічної підготовки та науково-методичного забезпечення цього процесу; уточнення завдань і методів дослідження; підготовка формувального експерименту. Під час експериментального здійснювалася дослідно-експериментальна перевірка робочих гіпотез, концептуальних положень, організаційно-педагогічних умов професійного становлення майбутніх учителів у процесі загальнопедагогічної підготовки; аналіз проміжних результатів дослідження; корекція експериментальних методик i науково-методичного забезпечення, їх апробація й упровадження в навчальний процес. Підсумково-узагальнювальний був спрямований на оброблення та систематизацію даних формувального етапу експерименту, порівняння їх 3 прогнозованими; узагальнення одержаних даних, формулювання загальних висновків i рекомендацій щодо впровадження результатів дослідження; визначення перспектив подальшого вивчення окресленої проблеми; підготовка та видання монографії; оформлення матеріалів науково-дослідної роботи. 
Слід акцентувати увагу на практичному значенні дослідження, яке полягає в розробленні та впровадженні технології професійного становлення майбутнього вчителя в процесі загальнопедагогічної підготовки. Запропонований комплекс організаційно-педагогічних умов, форм, методів, технологій передбачається використовувати з метою вдосконалення професійної підготовки вчителя загалом i його професійного становлення в процесі загальнопедагогічної підготовки зокрема для розробки лекційних курсів, спецкурсів i семінарських занять, практикумів та спецпрактикумів з педагогіки у ЗВО. Вони можуть доповнити зміст навчальних дисциплін: «Педагогіка», «Педагогіка вищої школи», «Методика викладання у вищій школі», «Основи педагогічної майстерності», «Методика виховної роботи» тощо. Практичне значення мають розроблені методичні рекомендації щодо професійного становлення студентів у процесі загальнопедагогічної підготовки, що, зокрема, знайшло відображення в авторських монографіях: «Професійне становлення майбутнього вчителя в процесі загальнопедагогічної підготовки: теорія і практика, «Загальнопедагогічна компетентність учителя: особливості, складники, шляхи формування»; навчальних посібниках: «100 складних ситуацій на уроках та поза уроками: шукаємо рішення», «Методика викладання у вищій школі», «Загальнопедагогічна підготовка до курсового та комплексного державного екзамену (освітньо-кваліфікаційний рівень «бакалавр»)», «Основи виховної діяльності вчителя фізичної культури».

Основні положення, результати й висновки планується в подальшому використовувати в дослідженнях $з$ теорії й методики професійної освіти, для розроблення галузевих стандартів нового покоління, застосовувати в підготовці педагогів за різними освітньокваліфікаційними та науковими рівнями.

Реалізацією конкретного педагогічного задуму стала розроблена технологія становлення майбутнього вчителя в процесі загальнопедагогічної підготовки, в основі якої лежать детерміновані цільовими настановами відповідні методологічні підходи; комплекс взаємопов'язаних і взаємообумовлених педагогічних впливів, дій, операцій, спрямованих на конкретний очікуваний результат - забезпечення якісного професійного становлення студентів. Технологія передбачає суб'єкт-суб'єктну взаємодію, педагогічну підтримку, спрямовані на включення студента в активну діяльність, що забезпечує успішність професійного становлення шляхом зміцнення мотиваційної основи його особистості, ціннісного ставлення до знань, формування міцного когнітивного фундаменту та безперервного професійного самовдосконалення 3 урахуванням принципів цілеспрямованості, послідовності і наступності його фаз, професійної самосвідомості, самоорганізації індивідуальних траєкторій руху до вершин професіоналізму, перспективності, практичної спрямованості, творчої активності, самостійності. Елементи педагогічної технології розраховані на їх відтворення, застосування, адаптацію до змінюваних умов, подальше вдосконалення та розвиток будь-яким викладачем, що здійснює загальнопедагогічну підготовку, a їх комплексне використання гарантує досягнення запланованих результатів. Органічною частиною педагогічної технології $\epsilon$ діагностичні процедури, котрі містять критерії, показники та інструментарій вимірювання загальнопедагогічної компетентності як результату професійного становлення. Етапи технологічного процесу професійного становлення (професійно-орієнтувальний, процесуально-діяльнісний, рефлексивно-коригувальний) відповідають його стадіям, узгоджуються 3 організаційно-педагогічними умовами й передбачають наступність i взаємозумовленість формування компонентів загальнопедагогічної компетентності. У технології домінують методи та форми, орієнтовані на позиціонування студентів як суб'єктів навчання та особистісно-професійного самовдосконалення (проблемні завдання; аналіз професійно-педагогічних відеофрагментів, розв'язання педагогічних ситуацій, моделювання індивідуальних творчих проектів, конкурси педагогічної майстерності тощо), котрі в поєднанні 3 сучасними ІКТ дають змогу розвивати всі компоненти становлення професіонала. 
Висновки та перспективи подальшого дослідження проблеми. Своєрідним свідченням результативності запропонованого підходу до розв'язання проблеми професійного становлення майбутнього вчителя в процесі загальнопедагогічної підготовки $є$ цитати суб'єктів цього процесу, студентів третього курсу факультетів фізичного виховання і спорту та іноземних мов, після вивчення базової педагогічної дисципліни «Педагогіка» (анонімні відповіді за методикою незакінчених речень).

«Особисто для мене педагогіка була дисиипліною, яка вразила нас своєю необхідністю. Чимало дисциплін, які ми вивчаємо, абстрактні і згодом їх не використовують. Цікаво те, що на парі, під час навчального прочесу ти можеш навчитися реальним практичним знанням. Ти вирішуєш ситуації, які дійсно можуть статися в житті. Відчула, щуо в мене змінилось ставлення до професії вчителя».

«Я вже відчув допомогу педагогіки в своїй роботі. Наведу маленький приклад. У моєму робочому колективі прачює шість чоловік, різних за характером, віком, інтересами. В однієї дівчини стались якісь внутрішні проблеми, щзо негативно відобразились на виконанні нею мого важливого доручення. Спочатку захотілось покарати ї̈, насварити, «наїхати»... Але завдяки знанням з педагогіки я стримав негативні емоції $і$ не зробив иього, скориставшись педагогічним прийомом, який допоміг мені і дівчині дійти до спільного знаменника в наших ділових стосунках. Я отримав, по-перше, велике задоволення, по-друге, перемогу над собою, а дівчина перемогла свій негативний внутрішній стан. Сьогодні в колективі проблем стало набагато менше».

"Я не сиджу на місиі, увесь час намагаюся прогресувати. Та ие мені досить важко вдається. Іноді хочеться здатись. Але приходиш на педагогіку і стаєш незадоволений своєю слабкістю, тому щзо знову отримуєш поштовх до подальшої боротьби з собою».

«Закінчивши вивчати педагогіку, я хотів би сказати, щуо не бажаю на цььому завершувати ї̈ вивчення. Я хочу надалі продовжувати пізнавати цюю науку, щоб застосовувати набуті знання у своєму житті».

«Мене важко зацікавити предметами, які мало пов'язані зі спортом, але педагогіка зуміла ие зробити й навіть стала одним з найулюбленіших предметів. 3 ї̈ допомогою я зміг відкорегувати свої плани, які прагну втілити у життя. Вона мені дала мотиваџію рости як майбутньому професіоналу і як особистості».

«Ніколи ще не думав, щуо ия дисиипліна настільки може вплинути на мене та на моє життя. І хоча я лише тільки почав цее усвідомлювати - я досяг неймовірних успіхів».

«Закінчивши вивчати педагогіку, я хотів би сказати, що вона мене надихнула не здаватись, почати вірити в себе та свої сили. За невеликий проміжок часу в моєму спорті, у моїи кар'єрі футболіста проявлялось багато поганого, мені хотілось все залишити, але після кожної пари яка йшла 120 хвилин, я знаходив натхнення та сили продовжувати. Я почав вірити в те, щзо я зможу досягнути ичілі».

\section{Список використаних джерел та літератури}

1. Акімова О. В., Каплінський В. В., Хамська Н. Б. Методичні рекомендації до комплексного екзамену для студентів спеціальності «Педагогіка вищої школи» освітньо-кваліфікаиійного рівня магістра. Вінниця : ТОВ «Фірма «Планер», 2015. 49 с.

2. Бернс Р. Развитие Я-конщепици и воспитание. М. : Прогресс, 1986. 420 с.

3. Гуревич Р. С., Каплінський В. В. Лекторська майстерність викладача вищої школи як важлива умова успішності викладацької діяльності. Наукова школа академіка I. А. Зязюна у праиях його соратників та учнів: мат. наук.-практ. конф. Х.: НТУ «ХПІ», 2017. С.13-17.

4. Захарченко В.М., Луговий В. І., Рашкевич Ю.М., Таланова Ж. В. Розроблення освітніх программ: Методичні рекомендаиіï/За ред.В. Г. Кременя. К.:ДП«НВЦ«Пріоритети», 2014. 120 с.

5. Зеер Э.Ф. Психология профессий: Учебн. пособие / Э.Ф.Зеер. - 3-е изд., перераб. и доп. М. : Издательский центр «Академия», 2007. 240 с.

6. Каплінський В. В. Загальнопедагогічна компетентність учителя: особливості, складники, иляхи формування: монографія. Вінниця: ТОВ «Нілан-ЛТД», 2016. 154 с. 
7. Каплінський В. В. Професійне становлення майбутнього вчителя в прочесі загальнопедагогічної підготовки: теорія і практика: монографія. Вінниця: «Твори», 2018. 492 с.

8. Каплінський В. В., Х Хорунжевський Л. Є. Специфіка комунікативних умінь як інструменту виховного впливу. Наукові записки ВДПУ ім. М. Коцюбинського. Сер. Педагогіка і психологія. 2011. Вип. 34. С. 64-68.

9. Концепція розвитку педагогічної освіти. Проект (13 березня 2018 р.). - Міністерство освіти і науки України, 2018. 21с.

10. Митина Л. М. Психология труда и профессионального развития учителя : Учебное пособие для студ. высш. пед. учеб. заведений [Текст]. М. : Академия, 2004. 320 с.

11. Орлов В. Професійне становлення особистості педагога у вимірах класичної методології. Науковий вісник Інституту професійно-технічної освіти НАПН Украӥни. Сер.: Професійна педагогіка. 2014. № 8. C. 103-111.

12. Професійне становлення особистості майбутнього вчителя: монографія / Акімова О.В., Галузяк B.M. та ін. Вінниця : «Твори», 2018. 340 с.

13. Стратегія розвитку педагогічної освіти в Україні: конщеепууальні положення / О.Г. Кучерявий; за наук. ред. член-кор. НАПН України Л.Б. Лук'янової; Інститут педагогічної освіти і освіти дорослих НАПН України. - Київ : ТОВ «ДКС-Центр», 2016. 43 с.

14. Lazarenko N. I., Kaplinski V. V. Higher Education in Ukraine: Ensuring the Quality of Education. International Scientific-Practical Conference Theoretical and applied researches in the field of pedagogy, psychology and social sciences. Kielce, 2016. P. 98-101.

\section{References (translated $\&$ transliterated)}

1. Akimova O. V., Kaplinskyi V. V., Khamska N. B. Metodychni rekomendatsii do kompleksnoho ekzamenu dlia studentiv spetsialnosti «Pedahohika vyshchoi shkoly» osvitno-kvalifikatsiinoho rivnia mahistra [Methodical Recommendations for the Complex Exam for Students of the Higher School Pedagogy Specialty of Master's Educational Qualification]. Vinnytsia: TOV «Firma «Planer», 2015. 49p.

2. Berns R. Razvytye Ya-kontseptsyy y vospytanye [Development of Self-concept and Education]. M.: Prohress, 1986. 420p.

3. Hurevych P.C., Kaplinskyi V.V. Lektorska maisternist vykladacha vyshchoi shkoly yak vazhlyva umova uspishnosti vykladatskoi diialnosti [Lecture Skills of High school Teachers' as an Important Condition of Success of Teaching Activity]. Naukova shkola akademika I. A.Ziaziuna u pratsiakh yoho soratnykiv ta uchniv: mat. nauk.-prakt. konf. Kh.: NTU «KhPI», 2017. Pp.13-17.

4. Zakharchenko V.M. Rozroblennia osvitnikh prohramm [The Development of Educational Programs]: Metodychni rekomendatsii / V.M.Zakharchenko, V.I.Luhovyi, Yu.M.Rashkevych, Zh.V.Talanova / Za red. V.H.Kremenia. K.: DP «NVTs «Priorytety», 2014. 120p.

5. Zeer E.F. Psykholohyia professyi [Occupational Psychology]: Uchebn. posobye / E.F.Zeer. - 3-e yzd., pererab. i dop. M.: Yzdatelskyi tsentr «Akademyia», 2007. 240p.

6. Kaplinskyi V. V. Zahalnopedahohichna kompetentnist uchytelia: osoblyvosti, skladnyky, shliakhy formuvannia [General Pedagogical Competence of the Teacher: Features, Components, Ways of Formation]: monohrafiia. Vinnytsia: TOV «Nilan-LTD», 2016. 154p.

7. Kaplinskyi V. V. Profesiine stanovlennia maibutnoho vchytelia $v$ protsesi zahalnopedahohichnoi pidhotovky: teoriia i praktyka [Professional Formation of the Future Teacher in the Process of General Pedagogical Preparation: Theory and Practice]: monohrafiia. Vinnytsia: «Tvory», 2018. 492p.

8. Kaplinskyi V. V., Khorunzhevskyi L. Ye. Spetsyfika komunikatyvnykh umin yak instrumentu vykhovnoho vplyvu [Specificity of Communicative Skills as a Tool of Educational Influence]. Naukovi zapysky VDPU im. M.Kotsiubynskoho. Ser. Pedahohika i psykholohiia. 2011. Vyp. 34. Pp. 64-68.

9. Kontseptsiia rozvytku pedahohichnoi osvity [The Concept of Development of Teacher Education]. Proekt (13 bereznia 2018 r.). - Ministerstvo osvity i nauky Ukrainy, 2018. 21p.

10. Mytyna L.M. Psykholohyia truda y professyonalnoho razvytyia uchytelia [Psychology of Work and Professional Development of Teachers]: Uchebnoe posobye dlia stud. vyssh. ped. ucheb. zavedenyi [Tekst]. M. : Akademyia, 2004. 320p.

11. Orlov V. Profesiine stanovlennia osobystosti pedahoha u vymirakh klasychnoi metodolohii [Professional Formation of the Teacher's Personality in the Dimensions of Classical Methodology]. Naukovyi visnyk Instytutu profesiino-tekhnichnoi osvity NAPN Ukrainy. Ser.: Profesiina pedahohika. 2014. № 8. Pp.103111.

12. Profesiine stanovlennia osobystosti maibutnoho vchytelia [Professional Formation of the Future Teacher's Personality]: monohrafiia / Akimova O.V., Haluziak V.M. ta in. Vinnytsia: «Tvory», 2018. 340p. 
13. Stratehiia rozvytku pedahohichnoi osvity $v$ Ukraini: kontseptualni polozhennia [Strategy for the Development of Teacher Education in Ukraine: Conceptual Provisions] / O.H.Kucheriavyi; za nauk. red. chlen-kor. NAPN Ukrainy L.B. Lukianovoi; Instytut pedahohichnoi osvity i osvity doroslykh NAPN Ukrainy. - Kyiv: TOV «DKS-Tsentr», 2016. 43p.

14. Lazarenko N.I., Kaplinski V.V. Higher Education in Ukraine: Ensuring the Quality of Education. International Scientific-Practical Conference Theoretical and applied researches in the field of pedagogy, psychology and social sciences. Kielce, 2016. Pp. 98-101.

Статтю отримано 17.10.2019 року

Прийнято до друку 18.11.2019 року 